\title{
THE EFFECT OF MS PHOTO STORY 3 ON STUDENTS' SPEAKING ACHIEVEMENT
}

\author{
Dila Charisma \\ English Education Department, Teacher Trainer and Education Faculty, \\ Muhammadiyah University of Cirebon, Indonesia \\ E-mail: dilla.charisma@umc.ac.id \\ Khomarudin \\ English Education Department, Teacher Trainer and Education Faculty, \\ Muhammadiyah University of Cirebon, Indonesia \\ E-mail: oemarbakrie0231@gmail.com
}

APA Citation: Charisma, D., \& Khomarudin. (2018). The effect of Ms Photo Story 3 on students' speaking achievement. Indonesian EFL Journal, 5(1), 77-84. doi: 10.25134/ieflj.v5i1.1613.

\begin{abstract}
Technology information and communication now takes the best attention from educators. It plays to be good or even better media in teaching and leraning process. Therefore, prospective English teachers should have good skill in creating new class atmosphere toward technology. They need to use technology to be the suitable media in learning English, especially speaking, since speaking is considered to be one of difficult skill. Ms Photo Story 3 is one of many computer applications that can be used as a media in teaching speaking. This present study focuses on the effect of Ms Photo Story 3 in improving prospective English teachers' speaking and the response of using Ms Photo Story 3 in learning English, especially speaking. Experiment with one group, pre-test, treatment and post-test were employed in this study. The results showed that there are increasing prospective English teachers' scores. It can be seen from the comparison score of pretest and posttest. Furthemore, the result from the questionaire revealed that the participants' response after using Ms Photo Story 3 in speaking class is categorized good. Thus, it can be concluded that Ms Photo Story 3 is effective in giving prospective English teachers experiences to create digital speaking.
\end{abstract}

Keywords: Ms Photo Story 3; prospective English teachers; speaking; teaching media; technology.

\section{INTRODUCTION}

Today, information and communication technology (ICT) is very popular in language teaching and learning. Teachers as facilitators are required to have the ability to provide technology-based learning media. Technological integration forces the teacher to improve the lesson and support students' learning (Mouze, 2011). Therefore, teachers, especially English teachers must be responsive to technology. ICT is a required and important asset of citizens in modern society (Wikan, 2010). Thus, all lines of society including teachers living in a modern environment should be able to understand technology. Further, Wikan (2010) states that in particular with the introduction of the internet in the 1990s, the belief in modern technology, as a kind of miracle cure for the enhancement of learning, increased considerably. This statement shows that technology is able to improve the quality of learning and change the classroom atmosphere to be more enjoyable accompanied by the ability of a teacher in the field of ICT and the introduction of students about computer science.

Sadik (2008) explains that within the last 10 years, digital cameras, editing software, authoring tools and electronic media outlets have encouraged teachers to utilize many more approaches and tools than ever before 


\section{Dila Charisma \& Khomarudin}

The effect of Ms Photo Story 3 on students' speaking achievement

to help students to construct their own knowledge and ideas to present and share them more effectively. It is in line with the trend that is rife in the lives of students that must be considered and used as a positive input for designing enjoyable learning activities. The generation that will be taught by prospective English teachers is young learners which are categorized into generation who are aware of technology at a very young age (Supri, 2015). In other words, the young learners are $\mathrm{Z}$ generation, the generation which was born after 2000 . The characteristcs of $\mathrm{Z}$ generation is developing mature in the era of computerization and internet networks.

Therefore, learning strategies using computers and software applications as learning media are very popular with students. As a result, second and foreign language teachers have the options to use technology in the classroom (Insani, Suherdi, \& Gustine, 2018). Therefore, technology is indicated as one of factors in the $21 \mathrm{st}$ century education. One of the computer software application is Ms Photo Story 3 where students are allowed to do speaking practice and create video strips with pictures and sounds in the project.

Speaking is considered to be difficult compared to the other skills. Therefore, to be able to speak fluently, students should have enough opportunities to speak the language. Yet, students who have low participation in speaking activity in the classroom lose their opportunity to practice their speaking skill which may cause poor speaking skill and achievement (Prabawa, 2016). Besides, junior and senior high school students are getting bored with monotonous language learning which does not contain technological elements. This is evidenced by many facts occur in the class, one of which is that students prefer to open a cellphone rather than listen to the teacher's explanation. Continuedly, at home, students prefer to play online games rather than repeat the lessons learned at school, students are also more interested in seeing YouTube, taking own pictures, making videos and uploading them on social media they have.

In accordance with the problems of students who are less interested in language teaching and learning due to the lack of teacher skills in technology to prepare learning media, this present study introduces one of the language learning media to promote students' speaking skill, MS Photo Story 3. This computer application software can be used as digital media in storytelling or digital storytelling. As Haigh and Hardy (2010) explain that digital storytelling is an integrated application of multiple media and software that utilizes the art and techniques with new methods, contributing to helping learners become involved in the learning situation. Besides, the potentials of digital storytelling for reflective, active, emancipative, and enjoyable learning, digital storytelling has been applied in the classroom as both a teaching tool and a learning tool in many innovative ways (Wang \& Zhan, 2010). Thus, it can be clonculded that teachers can use digital stories to deliver instructional content, including the presentation of an idea, illustration of a procedure, reinforcement of understanding, and a review of materials. Besides, students can create a story to share experiences, report findings, and reflect on understandings. Directly proportional to the explanation, Ms Photo Story 3 is the appropriate medium in attracting students' speaking enthusiasm in the context of storytelling.

Ms Photo Story 3 is software that can be applied to produce stories using digital photos, effects, sound tracks and narratives or descriptions that come from users' recorded voice. Hung (2012) in her study noted that Ms Photo Story 3 is reviewed and recommended to ESL or EFL teachers in speaking class for digital storytelling freely and easily. It can be ascertained that using Ms Photo Story 3 as a medium in learning speaking skill is able to create a pleasant digital experience in the classroom. Cohen (2012) also notes that the option of using 
photographs eases any reticence felt by participants to express their opinion.

Accordingly, photo story is the form of presenting photo images taken based on the topic or event needed so that it is arranged and each photo is able to "tell" with the intention of taking a meaning in those images. The emphasis of the photo image is the main element of photo story. In the learning process, the use of photo story is very effective, especially to explain an event and also be able to use as an enrichment of the material that has been given. Stories or events in the photo story allow students to learn gradually from simple to complex problems.

Reflecting on the previous studies, this present study aims to know whether Ms Photo Story 3 is effective or not to improve prospective English teachers' speaking skill. Furthemore, this study also aims to describe prospective English teachers' response in learning speaking skill using Ms Photo Story 3. To achieve those purposes, this present study addresses the following research questions: 1) Is Ms Photo Story 3 effective to improve prospective English teachers' speaking? and 2) How is prospective English teachers' response in learning speaking using Ms Photo Story 3?

\section{METHOD}

To achieve the purposes of the study, quantitative method was selected and an experiment with one group, pre-test, treatment and post-test proposed by Sugiyono (2011) was employed. The Faculty of Teacher Training and Education of Kuningan University and Muhammadiyah University of Cirebon were selected to be research location. Furthemore, the study was conducted in the classroom of English Education Department. The research subjects were students of prospective English teacher who contracted speaking subject in semester 2, totally 50 prospective English teachers.

Instruments used in this study were test and questionaire. The test was divided into two parts, namely pre-test and post-test. The scoring system is fundamental to represent three elements of speaking skill that should be mastered by the students. They are idea, fluency, and vocabulary (Brown, 2010). Besides, the questionnaire was designed to figure out students' perception toward Ms Photo Story 3 in improving their speaking skill. Data analysis was done to determine the effect of Ms Photo Story 3 in speaking achievement based on three criterias and calculate using the following formula:

$$
\text { Score }=\frac{\sum \text { earning score }}{\sum \text { maximum score }} \times 100
$$

Furthermore, the data were analyzed by comparing the scores of pre-test and posttest, then the n-gain is obtained with the formula:

$$
\langle g\rangle=\frac{\langle S \text { post }\rangle-\langle S \text { pre }\rangle}{\langle S \max \rangle-\langle S \text { pre }\rangle}
$$

\section{RESULTS AND DISCUSSION}

During the course of the lecture, gradual study activities were carried out with the following stages: a) doing situation analysis and literature study, b) developing research instruments, c) testing instrument validity, d) giving pretest to prospective English teachers in speaking skills, e) implementing the learning process with Ms Photo Story 3, f) Giving posttest to prospective English teachers in speaking skills using MS. Photo Story 3 , and g) analyzing data.

The results of this study get various data related to the skills of prospective English teachers in speaking through Ms Photo Story 3 and prospective English teachers' response towards the use of Ms Photo Story 3.

\section{The effectiveness of Ms Photo Story 3 to improve prospective English teachers' speaking}

The results on the effectiveness of Ms Photo Story 3 on the speaking achievement of prospective English teachers were assessed from the results of pretest and posttest. Furthemore, some aspects of indicators assessed from the effectiveness of speaking skills using Ms Photo Story 3 were the feasibility of idea descriptions with images imported into the application, fluency of 


\section{Dila Charisma \& Khomarudin}

The effect of Ms Photo Story 3 on students' speaking achievement

speech in describing images, and vocabulary development.

Ms Photo Story 3 was effective if the media has an influence on the prospective English teachers' speaking achievement, there is an increasing results of speaking skills seen from the assessment of idea development, fluency of speech, and the use of vocabulary variations. The rubric of the speaking skills assessment used in this study was adapted from Brown (2010) as presented in Table 1.

Table 1. Speaking scoring rubric

\begin{tabular}{|c|c|c|c|}
\hline Score & Idea & Fluency & Vocabulary \\
\hline 5 & $\begin{array}{l}\text { Excellent level of } \\
\text { description; } \\
\text { additional details } \\
\text { beyond the } \\
\text { required }\end{array}$ & $\begin{array}{l}\text { Smooth and fluid speech; } \\
\text { few to no hesitations; no } \\
\text { attempts to search } \\
\text { forwords; volume is } \\
\text { excellent. }\end{array}$ & $\begin{array}{l}\text { Excellent control of } \\
\text { language features; a } \\
\text { wide range of well } \\
\text { choosen vocabulary }\end{array}$ \\
\hline 4 & $\begin{array}{l}\text { Good level of } \\
\text { description; all } \\
\text { required } \\
\text { information } \\
\text { included }\end{array}$ & $\begin{array}{l}\text { Smooth and fluid speech; } \\
\text { few hesitations; a slight } \\
\text { search for words; } \\
\text { inaudible word or two }\end{array}$ & $\begin{array}{l}\text { Good language control; } \\
\text { good range of } \\
\text { relatively well-chosen } \\
\text { vocabulary }\end{array}$ \\
\hline 3 & $\begin{array}{l}\text { Adequate } \\
\text { description; } \\
\text { some additional } \\
\text { details } \\
\text { should be } \\
\text { provided }\end{array}$ & $\begin{array}{l}\text { Speech is relatively } \\
\text { smooth; some hesitation } \\
\text { and unevenness caused } \\
\text { by rephrasing and } \\
\text { searching for words; } \\
\text { volume wavers. }\end{array}$ & $\begin{array}{l}\text { Adequate language } \\
\text { control; vocabulary } \\
\text { range is lacking }\end{array}$ \\
\hline 2 & $\begin{array}{l}\text { Description lacks } \\
\text { some critical } \\
\text { details that make } \\
\text { it difficult for the } \\
\text { listener to } \\
\text { understand }\end{array}$ & $\begin{array}{l}\text { Speech is frequently } \\
\text { hesitant with some } \\
\text { sentences left } \\
\text { uncompleted; volume } \\
\text { very soft. }\end{array}$ & $\begin{array}{l}\text { Weak language } \\
\text { control; basic } \\
\text { vocabulary choice with } \\
\text { some words clearly } \\
\text { lacking }\end{array}$ \\
\hline 1 & $\begin{array}{l}\text { Description is so } \\
\text { lacking that the } \\
\text { listener cannot } \\
\text { understand }\end{array}$ & $\begin{array}{l}\text { Speech is slow, hesitant } \\
\& \text { strained except for } \\
\text { short memorized } \\
\text { phrases; } \\
\text { difficult to perceive } \\
\text { continuity in speech; } \\
\text { inaudible. }\end{array}$ & $\begin{array}{l}\text { Weak language } \\
\text { control; vocabulary } \\
\text { that is used does not } \\
\text { match the task }\end{array}$ \\
\hline
\end{tabular}

Students' pretest were carried out at the beginning of learning before Ms Photo Story 3 is implementated. Result of pretest showed that the average value of the indicator in the photo with the idea was 2.98 , the average value of the indicator on fluency was 2.88, and the average indicator on vocabulary use was 3.06. Thus, the average score of speaking skills was 2.97 (skilled enough). The details can be seen in Table 2 .

Table 2. Students' pretest score

\begin{tabular}{cccccc}
\hline No & Name & \multicolumn{3}{c}{ Criterias } & Average \\
\cline { 3 - 5 } & & Idea & Fluency & Vocabulary & \\
\hline & Total & 149 & 144 & 153 & 148,667 \\
& Average & 2,98 & 2,88 & 3,06 & 2,973 \\
& Precentage & 59,6 & 57,6 & 61,2 & 59,467 \\
\hline
\end{tabular}

In accordance with Table 2, the average score of idea development was 2.98, categorized in less skilled. In term of fluency in speaking, received an average score 2.88, categorized in less skilled. Most students have shown good value in straightforward, 
communicative, dialogical and interactive aspects. Yet, in the aspect of conformity with the language rules was still considered lack. In term of vocabulary development, the score obtained was 3.06, categorized skilled, but this category tends to be much better than other aspects. This is due to quite a lot of students' vocabulary mastery.
After idenfying each indicator of pretest scores, the next step was adding up the scores for each indicator and get the final score of the pretest. The final score of pretest was analyzed using Microsoft Excel 2010. The result of the analysis can be seen in Table 3.

Table 3. Pretest analysis

\begin{tabular}{lc}
\hline \multicolumn{1}{c}{ Statistic } & Statistic Pretest Score \\
\hline Sampel & 50 \\
Minimum Score & 2,00 \\
Maximum Score & 4,67 \\
Averages & 2,97 \\
\hline
\end{tabular}

Based on Table 3, it can be seen that from 50 students, the minimum score on the pretest result was 2.00 (skilled enough category) and the maximum pretest score was 4.67 (skilled category), while the average of pretest result wasa 2.97 (less skilled category). In addition, the frequency of obtaining pretest scores on the speaking skills of prospective English teachers can be seen in Table 4.

Table 4. Pretest score frequency

\begin{tabular}{clcc}
\hline \multicolumn{1}{c}{ Scores } & \multicolumn{1}{c}{ Categories } & Frequencies & Precentages \\
\hline $4,01-5,00$ & Very Skilled & 1 & $2 \%$ \\
$3,01-4,00$ & Skilled & 16 & $32 \%$ \\
$2,01-3,00$ & Skilled Enough & 32 & $64 \%$ \\
$1,01-2,00$ & Less Skilled & 1 & $2 \%$ \\
$0,00-1,00$ & Unskilled & - & \\
& Total & $\mathbf{5 0}$ & $\mathbf{1 0 0} \%$ \\
\hline
\end{tabular}

After conducting pre-test, the second step was to carry out the treatment using Ms Photo Story 3 for 4 meetings in order to introduce the digital media to prospective English teachers. This treatment was carried out in accordance with the learning steps in using Ms Photo Story 3. The steps of using Ms Photo Story 3 can be seen from Charisma's (2018), they are: 1) Creating students' own video stories by simply choosing "Begin a new story", 2) Importing pictures which students selected to use in the story and arranging in the correct order on the film strip, 3) Adding a title by simply selecting a picture then typing in text to add a title, 4) Narrating pictures and customizing motion by clicking the record button, then the motion of digital story can be changed by clicking "Customize Motion", 5) Adding background music to selected picture by clicking either "Select Music" or "Create Music", and 6) Saving the story to be the final step in creating a digital story through Ms Photo Story 3.

After conducting the treatments, the writers gave posttest. The posttest results were then directly processed by using Microsoft Excel 2007. The results of the posttest were seen from each indicator of speaking skills, namely the description of ideas from the picture, fluency in speaking, and vocabulary feasibility. The results of the average value of the development of ideas in speaking skills was equal to 4.4 (highly skilled), fluency of speech skills was 3.94 (skilled category), and the average value of vocabulary feasibility was 4.22 (highly skilled).

Viewing from the results of posttest average score, it can be seen that there was 
Dila Charisma \& Khomarudin

The effect of Ms Photo Story 3 on students' speaking achievement

an increasing score in each indicator. The skills can be seen in Table 5.

comparison of pretest and posttest speaking

Table 5. The comparison of students' pretest and posttest

\begin{tabular}{lccccccccc}
\hline \multicolumn{10}{c}{ Assessment Categories } \\
\hline Categories & $\begin{array}{c}\text { Pre } \\
\text { test }\end{array}$ & $\begin{array}{c}\text { Post } \\
\text { test }\end{array}$ & Increasing & $\begin{array}{c}\text { Pre } \\
\text { test }\end{array}$ & $\begin{array}{c}\text { Fluency } \\
\text { Post } \\
\text { test }\end{array}$ & Increasing & $\begin{array}{c}\text { Pre } \\
\text { Test }\end{array}$ & $\begin{array}{c}\text { Vocabulary } \\
\text { Post } \\
\text { Test }\end{array}$ & Increasing \\
\hline Total & 149 & 220 & 71 & 144 & 197 & 53 & 153 & 211 & 58 \\
Averages & 2,98 & 4,4 & 1,42 & 2,88 & 3,94 & 1,06 & 3,06 & 4,22 & 1,16 \\
Presentages & 59,6 & 88 & 28,4 & 57,6 & 78,8 & 21,2 & 61,2 & 84,4 & 23,2 \\
\hline
\end{tabular}

Based on Table 5, it can be expalined that the development of ideas increased by 1.42 , the fluency of speech increased by 1.06 , and the vocabulary increased by 1.16 . The significant increased was the category of ideas creativity.

After knowing the results of the pretest and posttest, both the average and the standard deviation, the next step was to calculate the normalized gain (n-gain) to see the increasing after the treatment. Calculating n-gain in this study was using Microsoft Excel 2010 which was adjusted to the n-gain formula. After calculating, it can be seen that the average score of $n$-gain for each indicator of prospective English teachers' speaking skill was 0.71, categorized in high level. To conclude with, Ms Photo Story 3 is effective in improving speaking skill. Ms Photo Story 3 motivates prospective English teachers in arranging ideas meaningfully.

\section{Prospective English teachers' response in} learning speaking using Ms Photo Story 3

As has been stated before, the data collected was not only from the test, but also from the questionnaire. The questionnaire was prepared and distributed for the purpose of securing responses. In the end of the meeting, the questionaire was distributed to get the data about students' perceptions and responses to Ms Photo Story 3 in teaching English especially as an effort to improve speaking skills. The questionnaire consisted of 5 questions using Likert Scale with a scale of 1-4. Observation data using a rating scale with a range of values in the form of numbers $(4,3,2,1)$ for the assessment of the learning process carried out by the teacher and students in learning, which means number 4 is very good, number 3 is good, number 2 is enough, and number 1 is less.

The questionnaire mainly focused on the response of prospective English teachers about making digital storytelling using Ms Photo Story 3 and its impact on developing English language skills. The questionnaire was given to 50 prospective English teachers and the result is shown in the following table.

Table 6. Recapitulation of prospective English teachers' response in learning speaking using Ms Photo Story 3

\begin{tabular}{|c|c|c|}
\hline No & Ms Photo Story 3 to increase students' speaking achivement & Averages \\
\hline 1 & $\begin{array}{l}\text { Ms Photo Story } 3 \text { makes users easy in conveying/describing something } \\
\text { verbally }\end{array}$ & 3,64 \\
\hline 2 & $\begin{array}{l}\text { Ms Photo Story } 3 \text { provides an exploration of the images that are } \\
\text { imported into the application to be retold }\end{array}$ & 3,42 \\
\hline 3 & $\begin{array}{l}\text { Feeling helped in speaking skills by imported images into Ms Photo } \\
\text { Stroy } 3 \text { application }\end{array}$ & 3,4 \\
\hline 4 & $\begin{array}{l}\text { Ms Photo Story } 3 \text { presents a menu in accordance with the wishes of } \\
\text { users in sorting images so that they can convey stories systematically }\end{array}$ & 3,42 \\
\hline 5 & $\begin{array}{c}\text { Ms Photo story is very helpful in learning speaking skills } \\
\text { Total } \\
\text { Averages }\end{array}$ & $\begin{array}{c}3,4 \\
17,28 \\
\mathbf{3 , 4 6}\end{array}$ \\
\hline
\end{tabular}


Table 6 showed that the question number 1 got 3.46 as the average score. It means that the question number 1 was categorized good. From the question number 2 , the average score was 3.42 which was categorized good. Going to the question number 3 , the average score was 3.4. It means that the good category was also achived. Looking at the question number 4 , the average score was 3.42 which was categorized good. Then, from the question number 5 , it got 3.4 as average score. It means that the category of the question number 5 was also good. From the table, it can be seen that good categories are achieved in each statement. Furthermore, the total averages were 3.46 which as categorized good. Thus, it can be concluded that learning by using Ms Photo Story 3 in speaking skills got a positive response. It means that Ms Photo Story 3 was very good to be implemented in the classroom to improve prospective English teachers' speaking skills.

Accordingly, Ms Photo Story 3 offers a practical and meaningful way to learn new technology such as how to use a digital camera, to get pictures and import to Ms Photo Story 3 by texting and voicing, which also motivates students and promotes independent learner. Furthermore, based on the result of questionaire, Ms Photo Story 3 also help prospective English teachers in creating idea based on the photos they arranged so that prospective English teachers are easy in describing something verbally. In accordance with the result of the questionaire, Ms Photo Story 3 also fasilitates prospective English teachers in conveying stories sistematically. It is because by using Ms Photo story 3, the photos or images can be changed and sorted easily.

\section{CONCLUSION}

Reflected from present findings, it can be concluded that Ms Photo Story 3 is effective to improve prospective English teachers' speaking skills. It can be seen from the score of pretest and there is increasing posttest score. After implementing Ms Photo Story 3

\section{https://journal.uniku.ac.id/index.php/IEFLJ/index}

in speaking class, the prospective English teachers can convey their ideas in making story meaningfully in a good film strips.

Based on the questionaire result, Ms Photo Story 3 is good to be used in learning speaking, since it can motivate prospective English teachers to produce their digital storytelling. This statement is in line with Charisma \& Khomarudin (2018) who state that Ms Photo Story 3 not only gives the students digital experiences in speaking and enhances students' information and communication technology knowledge, but also improves students' motivation, activeness and interest in speaking class.

Furthermore, Ms Photo Story 3 also gives experiences to prospective English teachers in speaking digitally beyond their classromm wall. It is in line with Yang (2015) who notes that students can create their digital stories anytime and anywhere at their convenience. In addition, Heo (2009) states that learners not only achieve a high degree of student autonomy but also exhibit improved motivation and enhanced skills in visual and digital literacy.

Ms Photo Story 3 is also recommended to use in improving writing skill. This statement is directly proportional to Limbong' (2010) view that Ms Photo Story 3 provides many different types of story maps to help students at all levels to further develop their imagination to enhance their writing ability based on story maps and being narrative interest catcher.

\section{ACKNOWLEDGEMENT}

The present study is supported by the Ministry of Research and Technology of Higher Education for Research Grant to Novice Lecturer No. 095/SP2H/LT/DRPM/II/2018.

\section{REFERENCES}

Brown, H. D. (2010). Language assessment: Principles and classroom practices. New York: Pearson Education.

Charisma, D., \& Khomarudin. (2018). Speaking through Ms Photo Story as digital storytelling. Proceedings of the $1^{\text {st }}$ International Conference on ELT (CONELT) "Teaching and Learning 


\section{Dila Charisma \& Khomarudin}

The effect of Ms Photo Story 3 on students' speaking achievement

English: Current Trends, Issues \& Practices", pp. 6-9.

Cohen, B. B. (2012). Conducting evaluation in contested terrain: Challenges, methodology and approach in an American context. Evaluation and Program Planning, 35, 189198.

Haigh, C., \& Hardy, P. (2010). Tell me a story - A conceptual exploration of storytelling in healthcare education. Nurse Education Today. doi: 10.1016/j.nedt.2010.08.001.

Heo, M. (2009). Digital storytelling: An ampirical study of the impact of digital storytelling on preservice teachers' self-efficacy and dispositions towards educational technology. Journal of Educational Multimedia and Hyptermedia, 8(4), 405-428.

Hung, C. M., Hwang, G. J., \& Huang, I. (2012). A Project-based digital storytelling approach for improving students' learning motivation, problem-solving competence and learning achievement. Educational Technology \& Society, 15(4), 368-379.

Insani, H. N., Suherdi, D., \& Gustine, G. G. (2018). Undergraduate students' perspectives in using Edmodo as an educational social network. English Review: Journal of English Education, 6(2), 61-68. doi: 10.25134/erjee.v6i2.1254.

Limbong, E. (2015). Digital storytelling of Microsoft Photo Story 3 for windows to improve the involvement of students in the process of learning English in the classroom. The Journal of English Literacy Education, 2(2), 108-111.
Mouze, C. (2011). Promoting urban teachers' understanding of technology, content, and pedagogy in the context of case development. Journal of Research on Technology in Education, 44(1), 1-29.

Prabawa, W. P. (2016). Speaking strategies used by Indonesian tertiary students. English Review: Journal of English Education, 4(2), 231-242.

Sadik, A. (2008). Digital storytelling: A meaningful technology-integrated approach for engaged student learning. Education Tech Research Dev, 56, 487-506 . doi: 10.1007/s11423-008-9091-8.

Sugiyono. (2011). Metode penelitian pendidikan. Bandung: Alfabeta

Supri, I. Z. (2015). Multimedia-based activity in young learners' English class: implementation and outcome. English Review: Journal of English Education, 3(2), 210-222.

Wang, S., \& Zhan, H. (2010). Enhancing teaching and learning with digital storytelling. International Journal of Information and Communication Technology Education, 6(2), 76-87.

Wikan, G. (2010). Does Ms Photo Story 3 make a difference? The views and experiences of a group of Norwegian secondary school teachers. Seminar.net-International Journal of Media, Technology and Lifelong Learning, 6(1), 136147.

Yang, R. (2011). Microsoft Photo Story for digital storytelling in the language classroom. Electronic Journal for English as a Second Language, 15(2). 